\title{
Longitudinal associations of in utero and early life near-roadway air pollution with trajectories of childhood body mass index
}

Jeniffer S. Kim, Tanya L. Alderete³, Zhanghua Chen, Fred Lurmann², Ed Rappaport', Rima Habre', Kiros Berhane ${ }^{1}$ and Frank D. Gilliland ${ }^{1 *}$

\begin{abstract}
Background: Evidence suggests that childhood near-roadway air pollution (NRAP) exposures contribute to increased body mass index (BMI); however, effects of NRAP exposure during the vulnerable periods including in utero and first year of life have yet to be established. In this study, we examined whether exposure to elevated concentrations of NRAP during in utero and/or first year of life increase childhood BMl growth.

Methods: Participants in the Children's Health Study enrolled from 2002 to 2003 with annual visits over a four-year period and who changed residences before study entry were included $(n=2318)$. Annual height and weight were measured and lifetime residential NRAP exposures including in utero and first year of life periods were estimated by nitrogen oxides $\left(\mathrm{NO}_{x}\right)$ using the California line-source dispersion model. Linear mixed effects models assessed in utero or first year nearroad freeway and non-freeway $\mathrm{NO}_{x}$ exposures and $\mathrm{BMl}$ growth after adjusting for age, sex, race/ethnicity, parental education, Spanish questionnaire, and later childhood near-road $\mathrm{NO}_{x}$ exposure.

Results: A two-standard deviation difference in first year of life near-road freeway $\mathrm{NO}_{x}$ exposure was associated with a 0 . $1 \mathrm{~kg} / \mathrm{m}^{2}$ (95\% confidence interval (Cl): 0.03, 0.2) faster increase in BMl growth per year and a $0.5 \mathrm{~kg} / \mathrm{m}^{2}(95 \% \mathrm{Cl}: 0.02,0.9)$ higher attained $\mathrm{BMl}$ at age 10 years.

Conclusions: Higher exposure to early life NRAP increased the rate of change of childhood BMI and resulted in a higher attained BMI at age 10 years that were independent of later childhood exposures. These findings suggest that elevated early life NRAP exposures contribute to increased obesity risk in children.
\end{abstract}

Keywords: Near-roadway air pollution, In utero exposures, Early life exposures, Childhood body mass index, Childhood obesity

\section{Background}

In the United States, approximately $32 \%$ of children 2 to 19 years were overweight or obese in 2011-2012 [1]. High prevalence of childhood obesity present significant clinical and public health problems since obese children are more likely to become obese adults $[2,3]$ and are at a greater risk for developing type 2 diabetes and cardiovascular disease [4-7]. Despite decades of diet and physical activity interventions, the

\footnotetext{
*Correspondence: gillilan@usc.edu

'Department of Preventive Medicine, Division of Environmental Health, Keck School of Medicine, Southern California Environmental Health Sciences Center, University of Southern California, 2001 N. Soto Street, Los Angeles, CA 90032, USA

Full list of author information is available at the end of the article
}

prevalence of childhood obesity remains high [8]. Previous studies have shown that increased near-roadway air pollution (NRAP) exposure $[9,10]$ and increased traffic density $[9,11]$ during childhood contributes to increased obesity risk in children. These findings suggest that modifiable environmental factors such as air pollution exposures may be contributing to the obesity epidemic $[9,12]$.

Longitudinal studies have shown that increased mid-childhood NRAP exposure and traffic density are associated with substantially increased body mass index (BMI) growth and a higher level of attained BMI at ages 18 [11] and 10 years [9]. Furthermore, increased childhood NRAP exposures, secondhand

(c) The Author(s). 2018 Open Access This article is distributed under the terms of the Creative Commons Attribution 4.0 International License (http://creativecommons.org/licenses/by/4.0/), which permits unrestricted use, distribution, and reproduction in any medium, provided you give appropriate credit to the original author(s) and the source, provide a link to the Creative Commons license, and indicate if changes were made. The Creative Commons Public Domain Dedication waiver (http://creativecommons.org/publicdomain/zero/1.0/) applies to the data made available in this article, unless otherwise stated. 
smoke (SHS), and maternal smoking during pregnancy were associated with increased BMI growth and a higher BMI at age 18 years [10]. To date, few studies have examined the effects of in utero and early childhood NRAP exposure on childhood BMI growth. Beyond mid-childhood exposures, early life periods like in utero and first year of life represent critical windows of air pollution exposure that may significantly alter childhood growth trajectories. One epidemiological study found that increased in utero ambient polycyclic aromatic hydrocarbon exposure, a marker for NRAP, was associated with higher BMI z-scores at age 5 and 7 years [13]. Additionally, recent data from the Boston Birth Cohort showed that in utero and early life exposures to ambient, fine particulate matter $\leq 2.5 \mu \mathrm{m}$ in diameter $\left(\mathrm{PM}_{2.5}\right)$ were significantly associated with increased risk of childhood overweight or obesity in children 2-9 years of age [14]. Although these studies suggest that elevated NRAP exposures during early life and childhood may increase future obesity risk, studies have not been entirely consistent as a European birth cohort recently reported no association of first 4 years of life NRAP exposure and childhood obesity at 4 years and 8 years of age [15].

Despite mixed findings, in utero and first year of life are periods of rapid growth that are highly susceptible to environmental influences [16]. Lasting effects of in utero and early life environmental exposures on childhood growth trajectories have been shown, and these early life stages are critical periods for the development of obesity $[16,17]$. For example, past studies have reported associations of increased in utero air pollution exposure and restricted fetal growth resulting in low birth weight (LBW) in full term babies [18-20]. Consequently, term babies with LBW have been shown to have postnatal catch-up growth which in turn has been associated with higher weight gain through infancy and childhood [21, 22]. Because in utero and first year of life are important developmental periods that influence growth, increased NRAP exposure during these critical periods may be contributing to future obesity risk through altered growth trajectories resulting in faster childhood BMI growth. The objective of this study was to examine the relationships between in utero and first year of life NRAP exposures with longitudinal measurements of BMI in a subset of Southern California children enrolled in the Children's Health Study (CHS). We hypothesized that higher in utero and/or first year of life NRAP exposure is associated with a faster increase in BMI growth over a 4-year follow up period and a higher attained BMI at age 10 years, and that these early life NRAP effects are independent of NRAP exposures later in childhood.

\section{Methods \\ Study design}

From 2002 to 2003, a cohort of kindergarten and first grade children were recruited from 45 public schools across 13 Southern California communities (Fig. 1). Details of CHS recruitment methods have been previously presented [23]. Informed consents were obtained from parents and assents from children. This study was reviewed and approved by the Institutional Review Board at the University of Southern California.

Height and weight were measured at baseline and at each subsequent, annual school visit. A trained technician measured height to the nearest centimeter and weight to the nearest pound $(0.45 \mathrm{~kg})$ of each child without shoes and with daily calibrations of the weight scale. BMI was calculated by weight/height ${ }^{2}$ (kilograms/meters ${ }^{2}$ ) and overweight and obese were defined using the Centers for Disease Control and Prevention (CDC) age-and sex-specific growth charts [24]. Parents completed baseline and yearly follow-up questionnaires pertaining to sociodemographic factors, characteristics of the home, and other covariates that were explored as potential confounders. These included age, sex, race/ethnicity, self-reported premature birth, maternal smoking during pregnancy, residential SHS, lifetime history of asthma, parental education (marker for socioeconomic status), if baseline questionnaire was completed in Spanish (marker for recent immigration status), and child's participation in team sports during the past year. A subset of children had birth weight and gestational age at birth which were extracted from the California vital statistics records. These data were obtained using the CDC LINKPLUS program which matched CHS children to the state's vital records database using several variables including child's name, sex, birthdate, as well as, mother's name, birthdate, zip code, and father's name.

\section{NRAP exposures}

Lifetime residential history was collected from all CHS participants at study enrollment and at each annual CHS visit via questionnaires, including move in and move out dates for each residence. NRAP exposures were estimated based on street level geocoded, residential locations from in utero to the most current follow-up date, which gave estimates of NRAP exposure for in utero, first year of life, and childhood periods. For in utero exposures, street address level data from study questionnaires (74.8\%) and birth certificates (25.2\%) were used. Residential addresses were uploaded to the ESRI geocoding database and software (ESRI Inc., Redlands, CA http://www.esri.com), geocoded to street level using the software, and assigned latitude and longitude coordinates. Google Earth and the Texas 


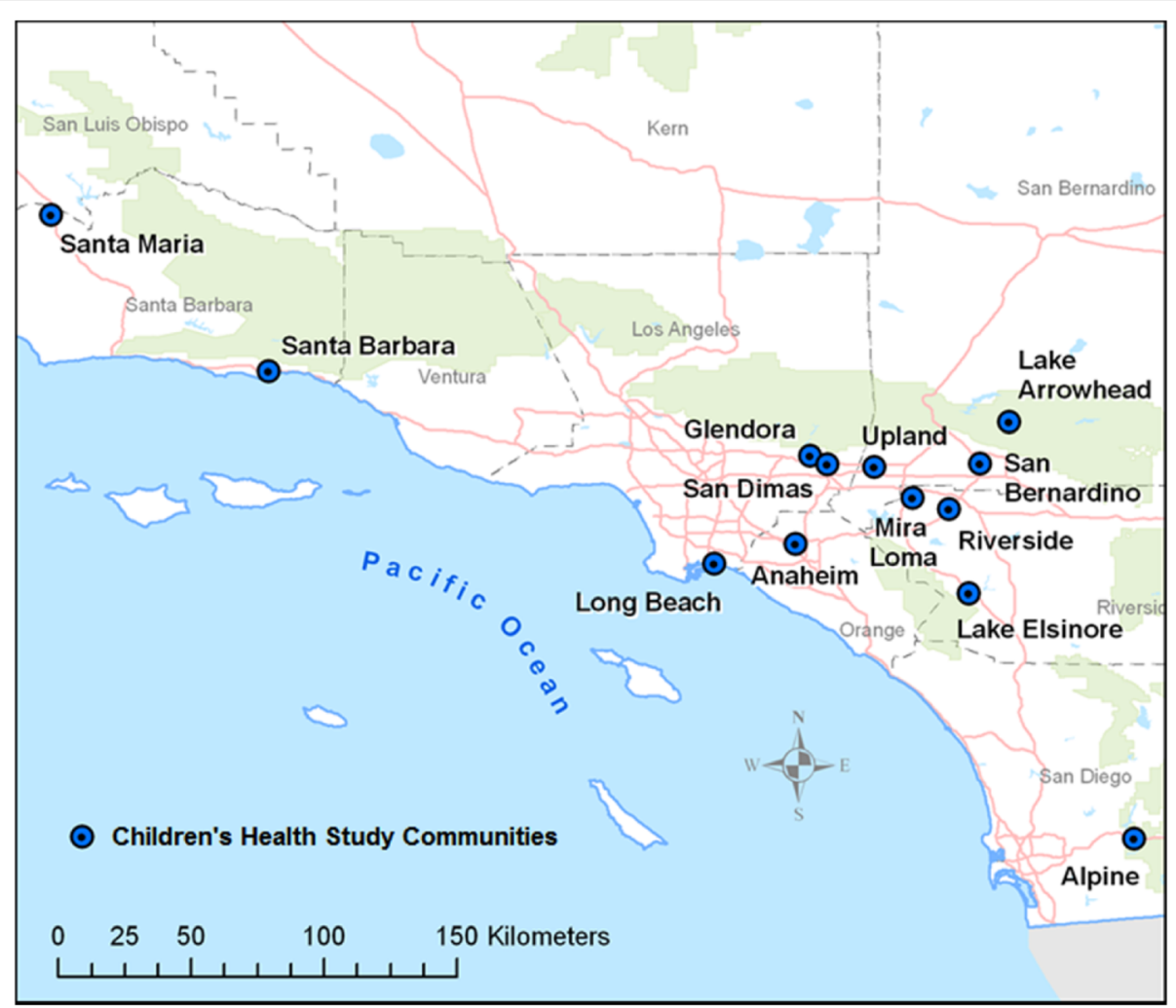

Fig. 1 Map of Children's Health Study Communities

A\&M geocoder [25] were also used to assign coordinates for a small number of problematic residential addresses.

The California line-source dispersion model (CALINE4) was used to estimate concentrations of traffic-related nitrogen oxides $\left(\mathrm{NO}_{\mathrm{x}}\right)$ for freeway and non-freeway roads using EMFAC2011 (for 1994-1999) and EMFAC2014 (for > 1999) vehicle emission rates, traffic volume, road geometry and meteorological conditions, including wind speed and direction, pollution mixing heights, and atmospheric stability [26]. Our roadway information is classified according to Feature Class Codes (FCC) which includes (1) primary highways with limited access (freeways), (2) primary roads without limited access, (3) secondary and connecting roads, and (4) local, neighborhood, and rural roads. Annual average traffic volumes from imbedded loop sensors provide $100 \%$ coverage for freeways and 95\% coverage for state highways (Class 2). The freeways have data for each link between interchanges whereas data for Class 2 roads is often extrapolated for longer distances to provide full coverage for all links. About $5 \%$ of smaller roads have traffic volume measurements and because these measurements are often on higher volume roads within their class, we assign the 25th percentile of annual traffic volume to all roads in the corresponding class. Exposure to NRAP was modeled using monthly average CALINE4 estimated $\mathrm{NO}_{\mathrm{x}}$ concentrations from freeway and non-freeway sources within $5 \mathrm{~km}$ of the residential coordinates during the in utero, first year of life, and mid-childhood periods. In utero near-road $\mathrm{NO}_{\mathrm{x}}$ exposure was defined as the nine-month average exposure prior to birth and first year of life near-road $\mathrm{NO}_{\mathrm{x}}$ exposure was defined as the twelve-month average exposure after birth. Lastly, to account for childhood near-road $\mathrm{NO}_{\mathrm{x}}$ exposures beyond the early life periods, childhood NRAP exposure was calculated as the average near-road $\mathrm{NO}_{x}$ exposure from 13 months of age through the 4-year study follow up period. Traffic pollutants are a complex mixture of gases and particles that include $\mathrm{NO}_{\mathrm{x}}$, carbon monoxide, elemental carbon, particulate matter, organic compounds, and polycyclic aromatic hydrocarbons amongst others. These NRAP exposures reflect increases in local vehicle emissions beyond background ambient levels. Therefore, NRAP was modeled using near-road $\mathrm{NO}_{x}$ from freeway and non-freeway roadways as a marker for traffic pollution as this measure is highly correlated with other pollutants estimated by CALINE4.

\section{Statistical methods}

Linear mixed effects models $[27,28]$ were fitted to estimate longitudinal relationships between BMI trajectory and in utero and first year of life NRAP exposures. We examined the associations of in utero or first year of life near-road $\mathrm{NO}_{\mathrm{x}}$ exposure from freeway and non-freeway 
roads with 1) the rate of change in BMI during 4 years of study follow up and 2) the attained BMI level at age 10 years. Due to the high correlation of in utero and first year of life near-road $\mathrm{NO}_{\mathrm{x}}$ exposures (correlation $r=0.8$ for freeway, $r=0.93$ for non-freeway), these two early life periods were analyzed in separate models.

Specifically, the following multi-level mixed effects model was used in the analysis. Let repeated measures of BMI $\left(Y_{\text {cij }}\right)$ with $\mathrm{c}$, $\mathrm{i}$, and $\mathrm{j}$ representing the study community, individual, and year of BMI measurement, respectively. Then,

Level 1: $\mathrm{Y}_{\mathrm{cij}}=\mathrm{a}_{\mathrm{ci}} \mathrm{a}_{\mathrm{ci}}+\mathrm{b}_{\mathrm{ci}}\left(\mathrm{t}_{\mathrm{cij}}-\mathrm{C}\right)+\gamma_{1}\left(\mathrm{E}_{\mathrm{Fij}}-\mathrm{E}_{\mathrm{Fi}}\right)+\gamma_{2} \mathrm{~W}_{\mathrm{ij}}+\varepsilon_{\mathrm{cij}}$.

Level 2a (level): $a_{\mathrm{ci}}=\mathrm{a}_{\mathrm{c}}+\alpha_{1} \mathrm{E}_{\mathrm{Ui}}+\alpha_{2} \mathrm{E}_{\mathrm{Fi}}+\alpha_{3} \mathrm{Z}_{\mathrm{i}}+\delta_{\mathrm{ci}}$

Level 2b (growth): $b_{c i}=\beta_{0}+\beta_{1} E_{U i}+\beta_{2} E_{F i}+\beta_{3} Z_{i}+\sigma_{c i}$

Level 3a: $\mathrm{a}_{c}=\alpha_{0}+\varepsilon_{\mathrm{c}}$

In Level $1, t_{c i j}$ is the age of participants at each visit centered by age $C$ (10 years), and $\gamma_{1}$ represents cross-sectional association between year to year fluctuations of near-road $\mathrm{NO}_{x}$ with follow up BMI measure at each study visit. $E_{F i j}$ reflects average near-road $\mathrm{NO}_{\mathrm{x}}$ exposure for the time between each subsequent follow up visit and $E_{F i}$ is the average childhood near-road $\mathrm{NO}_{\mathrm{x}}$ exposure from 13 months of age till last height/weight measure in 2006-2007 school year. Importantly, in this analysis we wanted to elucidate associations of in utero or first year of life near-road $\mathrm{NO}_{\mathrm{x}}$ exposures $\left(\mathrm{E}_{\mathrm{Ui}}\right)$ with BMI growth independent of childhood near-road $\mathrm{NO}_{\mathrm{x}}$ exposures. Therefore, the mixed model also includes average childhood near-road $\mathrm{NO}_{\mathrm{x}}$ exposures $\left(E_{F i}\right)$ while accounting for yearly deviations of near-road $\mathrm{NO}_{\mathrm{x}}$ during this follow-up period $\left(\mathrm{E}_{\mathrm{Fij}}-\mathrm{E}_{\mathrm{Fi}}\right)$.

In levels $2 \mathrm{a}$ and $2 \mathrm{~b}, \alpha_{1}$ and $\beta_{1}$ correspond to estimated effects of in utero near-road $\mathrm{NO}_{\mathrm{x}}$ exposure (or first year of life) on attained BMI level at age 10 years and the growth of BMI during the follow-up period, respectively. Whereas, $\alpha_{2}$ and $\beta_{2}$ correspond to estimated effects of childhood near-road $\mathrm{NO}_{\mathrm{x}}$ exposure on attained BMI level at age 10 years and the growth of BMI during the childhood period, respectively. Furthermore, $\alpha_{3} Z_{i}$ denotes adjustment factors for time-independent covariates at BMI level at age $10, \beta_{3} Z_{i}$ are adjustment factors for BMI growth during follow-up, $\varepsilon_{\mathrm{cij}}, \varepsilon_{\mathrm{c}}, \delta_{\mathrm{ci}}$ and $\sigma_{\mathrm{ci}}$ reflect error terms at each level of model to account for the random variations across communities and internal correlations of repeated measures from each subject over time. In addition, nonlinearity of BMI growth trajectory was tested by looking at the slope of BMI growth over time from baseline age 6.5 years to 10 years. We found no deviations from a linear trend as this is a relatively short period of growth $\sim 3.5$ years, and children in this age range have not yet reached puberty where growth tends to be nonlinear. Therefore, linear BMI growth was considered in the final analysis.
The current analysis included 2318 children who: 1) completed a baseline questionnaire, 2) had at least two measures of BMI across the 4-year study follow-up period, 3) had NRAP exposure data for the time windows of interest, and 4) moved homes prior to study enrollment to avoid collinearity between NRAP exposures during the in utero or first year of life periods with later childhood exposures (Fig. 2; Additional file 1). Children who lived in the same residence from birth through follow-up had a high correlation of NRAP exposures across each time period, therefore all analyses were restricted to "Movers". "Movers" were subjects who had a change in address between the in utero period and study enrollment that resulted in a move farther than or equal to $500 \mathrm{~m}$. This selection method allowed us to look at later NRAP exposures in childhood in the same model as the early life exposures, in utero and first year of life. In the "Movers" group, NRAP exposure periods had lower correlations, which allowed us to use the modeling framework described.

Mixed effects models were used to examine age-adjusted associations between baseline characteristics and BMI growth as well as attained BMI at age 10 years. These characteristics were identified as confounders and included in the final model if they resulted in $\mathrm{a} \geq 10 \%$ change in the effect estimate for BMI growth or attained BMI at age 10 years. Of the identified potential confounders, age, sex, race/ethnicity, parental education, and Spanish baseline questionnaire were included as confounders in the final model. Furthermore, effect modification by sex and race/ethnicity was tested using interaction terms in the full model. Effect estimates of NRAP exposure on BMI growth as well as attained BMI level at age 10 years are reported for a two-standard deviation (SD) difference in near-road freeway or non-freeway $\mathrm{NO}_{x}$ exposures during each exposure window. Statistical significance was based on a two-sided $p<0.05$. All analyses were performed in SAS, version 9.4 (SAS, Institute, Cary, NC).

\section{Results}

Baseline characteristics are reported in Table 1. At study entry, the mean age was 6.5 years (SD: 0.7 ) and $50.6 \%$ were male. Approximately $29 \%$ of children were overweight or obese using CDC growth chart cutoffs [24] with a mean BMI percentile of 60.5 (SD: 30.1) at study entry. Children were predominately Hispanic (56\%) or Non-Hispanic White (33\%), where $22 \%$ of the parents completed the baseline questionnaire in Spanish, which was used a marker of recent immigration status. On average, more than half of the children included in this study had parents with an education level above high school. SHS exposure was relatively low where $7 \%$ of mothers smoked during pregnancy and 5\% of children 


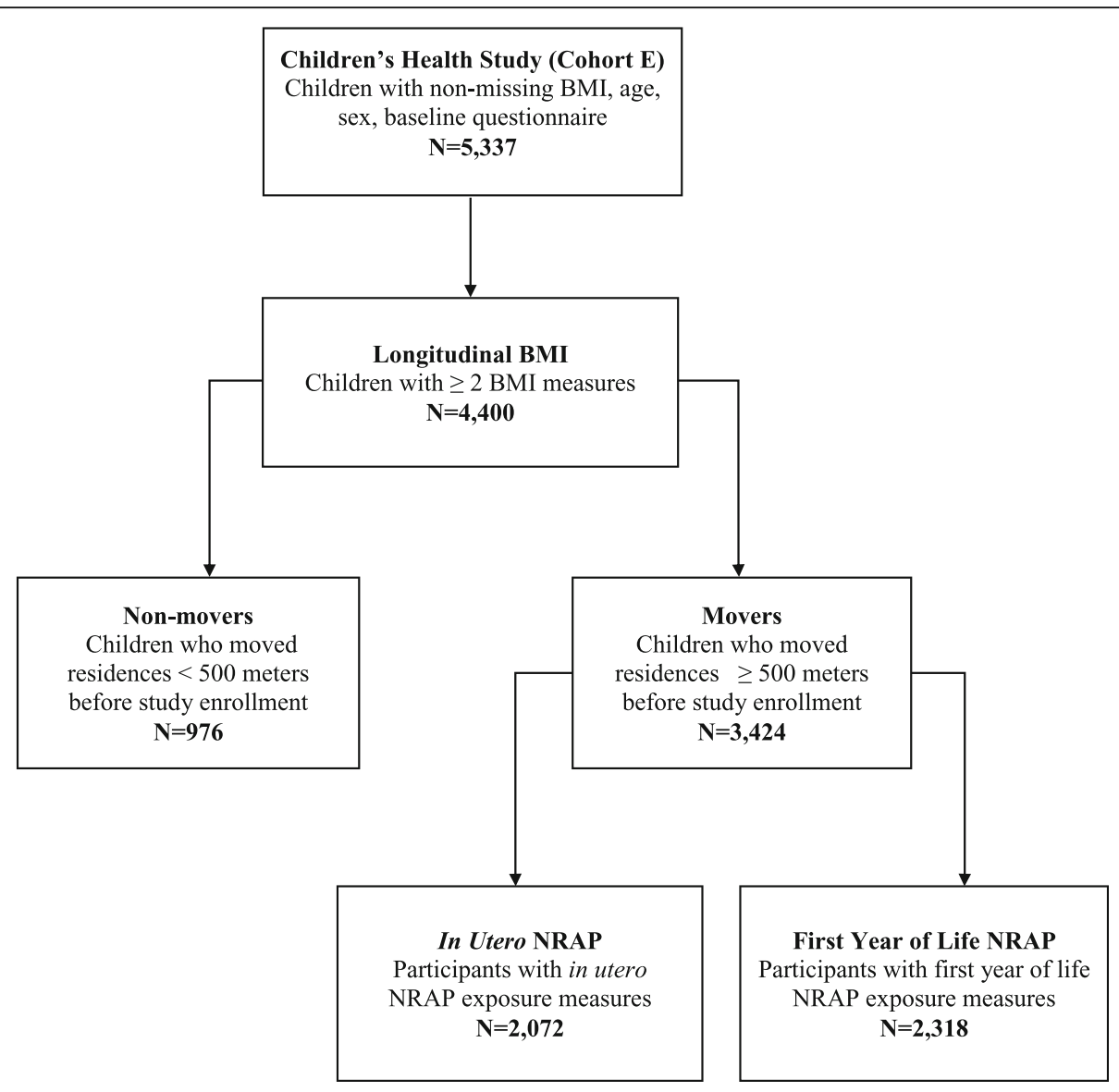

Fig. 2 Flow Chart of Children Enrolled in the Children's Health Study from 2002 to 2003 Included and Excluded from the Current Analysis

lived in homes where someone smoked daily in the presence of the child. At the end of the study follow up period, the mean age of children was 9.5 years (SD: 1.2).

Age-adjusted associations between each baseline characteristic and BMI growth trajectory and attained BMI at age 10 years are also shown in Table 1. Briefly, BMI growth through the study period was associated with baseline overweight/obesity status, sex, race/ethnicity, parental education, Spanish questionnaire, residential SHS as well as participating in an organized team sport $(p<0.05$ for each characteristic). BMI at age 10 years was associated with baseline overweight/obesity status, race/ethnicity, parental education, Spanish questionnaire, residential SHS, and participating in an organized team sport ( $p<0.05$ for each characteristic). The correlation between in utero and childhood freeway NRAP exposures was $0.35(p<0.0001)$ and the correlation between the first year of life and childhood freeway NRAP exposures was $0.58(p<0.0001)$ (Additional file 1$)$.

Because our analysis was limited to movers only, comparison of baseline characteristics of movers and non-movers can be found in Additional file 2. Movers were slightly older at baseline $(6.5$ years, $\mathrm{SD}=0.7)$ compared to non-movers (6.3 years, $\mathrm{SD}=0,7$ ). Racial/ ethnics groups differed between movers and non-movers with more Hispanic children in the non-movers group, $63 \%$ versus $56 \%$ in movers. Movers had more parents with an above high school education (62\%) compared to non-movers (51\%) and non-movers had more parents who filled out the baseline questionnaire in Spanish (37\%) than movers (22\%). Movers had a higher participation in organized team sports $(42 \%)$ than non-movers (34\%). Movers and non-movers did not differ in obesity status, sex, self-reported premature birth, maternal smoking during pregnancy, residential second-hand smoke, and lifetime history of asthma.

Residential NRAP exposures measured in near-road $\mathrm{NO}_{\mathrm{x}}$ for freeway and non-freeway sources for in utero, first year of life and childhood periods are described in Table 2.

Mean near-road $\mathrm{NO}_{\mathrm{x}}$ exposures from freeway roadways during in utero, first year of life, and childhood were 16.7 parts per billion (ppb) (SD: 20.1), $16.2 \mathrm{ppb}$ (SD: 19.5), and $15.1 \mathrm{ppb}$ (SD: 18.9), and mean near-road $\mathrm{NO}_{\mathrm{x}}$ exposures from non-freeway roadways during in utero, first year of life, and childhood were $10.3 \mathrm{ppb}$ (SD: 
Table 1 Baseline characteristics and age-adjusted associations with BMI growth and BMI at age 10 years in children enrolled in the longitudinal Children's Health Study ${ }^{a}$

\begin{tabular}{|c|c|c|c|}
\hline Characteristic & $\mathrm{n}(\%)^{\mathrm{b}}$ & $\begin{array}{l}\text { Associations with BMl growth } \\
(95 \% \mathrm{Cl})\end{array}$ & $\begin{array}{l}\text { Associations with } \mathrm{BMl} \text { at Age } 10 \text { years } \\
(95 \% \mathrm{Cl})\end{array}$ \\
\hline \multicolumn{4}{|c|}{ Overweight/Obesity Status $^{d}$} \\
\hline Normal & $1651(71.2)$ & reference & reference \\
\hline Overweight & $320(13.8)$ & $0.4(0.3,0.5)$ & $4.1(3.8,4.5)$ \\
\hline Obese & $347(15.0)$ & $0.7(0.7,0.8)$ & $9.0(8.6,9.3)$ \\
\hline \multicolumn{4}{|l|}{ Sex } \\
\hline Female & $1145(49.4)$ & reference & reference \\
\hline Male & $1173(50.6)$ & $0.06(0.004,0.1)$ & $0.3(-0.06,0.7)$ \\
\hline \multicolumn{4}{|l|}{ Race/Ethnicity } \\
\hline White & $771(33.3)$ & reference & reference \\
\hline Hispanic & $1290(55.7)$ & $0.3(0.2,0.4)$ & $1.9(1.6,2.3)$ \\
\hline Black & $72(3.1)$ & $0.2(-0.02,0.3)$ & $1.2(0.1,2.2)$ \\
\hline Asian/Pacific Islander & $67(2.9)$ & $0.2(-0.006,0.4)$ & $0.9(-0.2,2.0)$ \\
\hline Other & $114(4.9)$ & $0.2(0.04,0.3)$ & $0.7(-0.2,1.5)$ \\
\hline \multicolumn{4}{|l|}{ Parental Education } \\
\hline Less than high school & $410(18.4)$ & reference & reference \\
\hline High school & $430(19.3)$ & $-0.2(-0.3,-0.06)$ & $-1.0(-1.6,-0.5)$ \\
\hline Above high school & $1389(62.3)$ & $-0.3(-0.4,-0.2)$ & $-2.0(-2.4,-1.4)$ \\
\hline \multicolumn{4}{|l|}{ Spanish Questionnaire ${ }^{\mathrm{e}}$} \\
\hline No & $1818(78.4)$ & reference & reference \\
\hline Yes & $500(21.6)$ & $0.2(0.2,0.3)$ & $1.7(1.3,2.1)$ \\
\hline \multicolumn{4}{|c|}{ Self-Reported Premature Birth } \\
\hline No & $2003(88.9)$ & reference & reference \\
\hline Yes & $251(11.1)$ & $-0.01(-0.1,0.08)$ & $-0.6(-1.1,0.02)$ \\
\hline \multicolumn{4}{|c|}{ Maternal Smoking During Pregnancy } \\
\hline No & $2083(92.7)$ & reference & reference \\
\hline Yes & $164(7.3)$ & $-0.01(-0.1,0.1)$ & $-0.5(-1.2,0.2)$ \\
\hline \multicolumn{4}{|c|}{ Residential Second-Hand Smoke ${ }^{f}$} \\
\hline No & $2110(93.2)$ & reference & reference \\
\hline Yes, child is home & $110(4.9)$ & $0.1(0.02,0.2)$ & $0.3(0.07,0.6)$ \\
\hline Yes, child is not home & $44(1.9)$ & $0.1(-0.04,0.2)$ & $0.2(-0.2,0.5)$ \\
\hline \multicolumn{4}{|l|}{ Lifetime History of Asthma } \\
\hline No & $1928(85.1)$ & reference & reference \\
\hline Yes & $338(14.9)$ & $-0.04(-0.1,0.008)$ & $0.09(-0.08,0.2)$ \\
\hline \multicolumn{4}{|l|}{ Organized Team Sport ${ }^{\mathrm{g}}$} \\
\hline No & $1141(57.8)$ & reference & reference \\
\hline Yes & $832(42.2)$ & $-0.08(-0.1,-0.04)$ & $-0.2(-0.3,-0.09)$ \\
\hline
\end{tabular}

${ }^{a}$ This analysis includes a subset of the Children's Health Study participants who had available NRAP exposure data for in utero or first year of life periods, at least two measures of BMI during study follow up period, completed a baseline questionnaire, and had moved homes at least once before study enrollment

${ }^{\mathrm{b}}$ First observation of participant with NRAP exposures $(n=2318)$; variable denominators may differ due to missing values.

${ }^{\mathrm{C} A g e-a d j u s t e d}$ association for each characteristic with BMI growth over study follow up period and attained BMI at age 10 years

${ }^{\mathrm{d} O v e r w e i g h t /}$ Obesity status: Normal is <85th percentile of age-, sex-specific BMI using 2000 CDC growth chart, overweight is $85-95$ th percentile of age-, sex-

specific BMI, obese is $\geq 95$ th percentile of age-, sex- specific BMI.

e Spanish Questionnaire is if parent filled out baseline questionnaire in Spanish and serves as a surrogate measure for recent immigration.

${ }^{f}$ Residential second-hand smoke is if anyone living in the child's home smokes daily inside the home.

${ }^{g}$ Organized team sport is if the child played outdoors in any organized team sport at least twice a week during the past year 
Table 2 Residential NRAP exposures from freeway and nonfreeway sources for in utero, first year of life, and childhood periods in children in the CHS

\begin{tabular}{lllll}
\hline Exposure Period & Mean $\pm \mathrm{SD}$ & Median & IQR & Range \\
\hline Freeway $\mathrm{NO}_{x}(\mathrm{ppb})$ & & & & \\
$\quad$ In utero & $16.7 \pm 20.1$ & 10.8 & $4.4-22.1$ & $0-233.3$ \\
$\quad$ First year of life & $16.2 \pm 19.5$ & 10.4 & $4.1-21.9$ & $0-304.2$ \\
$\quad$ Childhood & $15.1 \pm 18.9$ & 9.6 & $4.6-18.1$ & $0-351.0$ \\
Non-Freeway $\mathrm{NO}_{x}(\mathrm{ppb})$ & & & \\
In utero & $10.3 \pm 7.4$ & 8.7 & $5.2-13.7$ & $0.0003-74.0$ \\
First year of life & $9.3 \pm 6.7$ & 7.9 & $4.6-12.2$ & $0.0003-77.4$ \\
Childhood & $6.2 \pm 4.7$ & 5.2 & $3.2-7.6$ & $0.09-65.7$ \\
\hline
\end{tabular}

7.4), $9.3 \mathrm{ppb}$ (SD: 6.7), and 6.2 ppb (SD: 4.7), respectively.

\section{Associations of early life NRAP exposures with childhood BMI}

First year of life exposures to NRAP from freeway roads were positively associated with BMI at age 10 years and BMI growth during study follow up and these associations were independent of mid-childhood NRAP exposures (Table 3).

For first year of life (model 2), a 39.1 ppb difference in near-road freeway $\mathrm{NO}_{\mathrm{x}}$ exposure was significantly associated with a $0.1 \mathrm{~kg} / \mathrm{m}^{2}$ (95\% confidence interval (CI): $0.03,0.2)$ faster increase in BMI per year resulting in a $0.5 \mathrm{~kg} / \mathrm{m}^{2}$ (95\% CI: 0.02, 0.9) higher BMI at age 10 years. For in utero (model 1), a $40.1 \mathrm{ppb}$ difference in near-road freeway $\mathrm{NO}_{\mathrm{x}}$ exposure was associated with a $0.05 \mathrm{~kg} / \mathrm{m}^{2}$ (95\% CI: $\left.-0.02,0.1\right)$ faster increase in BMI per year and a $0.1 \mathrm{~kg} / \mathrm{m}^{2}(95 \% \mathrm{CI}$ : $-0.3,0.5)$ higher BMI at age 10 years; however, these estimates did not reach statistical significance after adjusting for confounders (Table 3).

Table 3 Effects of in utero/first year of life and childhood freeway $\mathrm{NO}_{x}$ exposures on 4-year childhood BMI trajectories in CHS children

\begin{tabular}{lll}
\hline $\begin{array}{l}\text { Freeway } \mathrm{NO}_{x} \\
(\mathrm{ppb})\end{array}$ & $\begin{array}{l}\text { BMI Growth Per } \\
\text { Year }^{\mathrm{a}} \\
\text { Effect }(95 \% \mathrm{Cl})\end{array}$ & $\begin{array}{l}\text { BMl at Age 10 } \\
\text { Years }^{\mathrm{a}} \\
\text { Effect }(95 \% \mathrm{Cl})\end{array}$ \\
\hline
\end{tabular}

Model 1

$\begin{array}{lll}\text { In utero }(n=2072) & 0.05(-0.02,0.1) & 0.1(-0.3,0.5) \\ \text { Childhood } & -0.02(-0.1,0.05) & 0.05(-0.4,0.5)\end{array}$

Model 2

$$
\begin{array}{lll}
\text { First year of life }(\mathrm{n}=2318) & 0.1(0.03,0.2)^{*} & 0.5(0.02,0.9)^{*} \\
\text { Childhood } & -0.06(-0.1,0.02) & -0.1(-0.6,0.3)
\end{array}
$$

${ }^{\mathrm{a} B M I}$ growth $\left(\mathrm{kg} / \mathrm{m}^{2}\right)$ over study follow up and difference in attained BMI at age 10 years scaled to 2 standard deviations of in utero freeway NOx exposure with $40.1 \mathrm{ppb}$, first year of life freeway NOx with $39.1 \mathrm{ppb}$, and childhood freeway NOx with $37.8 \mathrm{ppb}$ ${ }^{*} p<0.05$
In contrast, non-freeway NRAP exposures during mid-childhood were associated with BMI at age 10 years and BMI growth while early life non-freeway NRAP exposures showed no significant association (Table 4). Additionally, near-road total $\mathrm{NO}_{\mathrm{x}}$ exposures were similar in magnitude to that of near-road freeway NOx exposures (Additional file 3).

Based on tests for interaction and the analysis stratified by effect modifiers, there was little evidence to support differences in effects of early life freeway NRAP exposure by sex (males versus females), race/ethnicity (Non-Hispanic Whites versus Hispanics), and baseline overweight/obese status (overweight/obese versus normal BMI) (Additional files 4, 5 and 6). In a subsample of children who had complete data of birth weight and gestational age $(n=2129)$, birth weight and gestational age did not significantly change the effects of in utero or first year of life near-road freeway $\mathrm{NO}_{\mathrm{x}}$ exposure on BMI growth and BMI at age 10 years (Additional file 7). We also explored effects of in utero and first year of life ambient $\mathrm{PM}_{2.5}$ exposures on childhood BMI trajectory however we did not see any significant associations (Additional file 8). We conducted further sensitivity analysis comparing independent contributions of in utero or first year of life near-road freeway $\mathrm{NO}_{\mathrm{x}}$ exposures without adjustments of mid-childhood exposures on BMI trajectory for movers and non-movers to assess possibility of selection bias (Additional file 9). We found similar growth trajectories amongst movers and non-movers when looking at in utero or first year of life NRAP exposures.

\section{Discussion}

In our study population of school-aged children in Southern California, higher first year of life NRAP from freeway sources were associated with faster increases in BMI during childhood after adjusting for confounders such as age, sex, race/ethnicity, parental education, Spanish questionnaire, and mid-childhood NRAP exposures. These longitudinal associations were independent of mid-childhood NRAP exposures and resulted in significant differences in BMI at age 10 years, suggesting that early life NRAP exposures may represent important windows of exposure that increase risk for developing childhood obesity. Previous studies of this cohort have shown that increased mid-childhood NRAP was associated with increased BMI growth where children in the highest $10 \%$ of non-freeway $\mathrm{NO}_{\mathrm{x}}$ exposure showed a $0.39 \mathrm{~kg} / \mathrm{m}^{2}$ higher BMI at age 10 years and a $0.087 \mathrm{~kg} /$ $\mathrm{m}^{2}$ faster increase in BMI per year when compared to those in the lowest $10 \%$ of exposure using a similar modeling approach [9]. We found consistent results as those reported in Jerrett et al. 2014 using our childhood, non-freeway NRAP exposure in our subset of children 
Table 4 Effects of in utero/first year of life and childhood nonfreeway $\mathrm{NO}_{x}$ exposures on 4-year childhood BMl trajectories in children in $\mathrm{CHS}$

\begin{tabular}{|c|c|c|}
\hline Non-Freeway $\mathrm{NO}_{x}(\mathrm{ppb})$ & $\begin{array}{l}\text { BMl Growth Per } \\
\text { Year }^{\mathrm{a}} \\
\left.\text { Effect }^{(95 \%} \mathrm{Cl}\right)\end{array}$ & $\begin{array}{l}\text { BMl at Age } 10 \\
\text { Years }^{\mathrm{a}} \\
\text { Effect (95\% Cl) }\end{array}$ \\
\hline \multicolumn{3}{|l|}{ Model 1} \\
\hline In utero $(n=2072)$ & $0.03(-0.05,0.1)$ & $0.1(-0.3,0.6)$ \\
\hline Childhood & $0.08(-0.007,0.2)$ & $0.6(0.08,1.03)^{*}$ \\
\hline \multicolumn{3}{|l|}{ Model 2} \\
\hline First year of life $(n=2318)$ & $-0.02(-0.1,0.06)$ & $-0.07(-0.5,0.4)$ \\
\hline Childhood & $0.1(0.01,0.2)^{*}$ & $0.6(0.1,1.1)^{*}$ \\
\hline
\end{tabular}

${ }^{\mathrm{a} B M l}$ growth $\left(\mathrm{kg} / \mathrm{m}^{2}\right)$ over study follow up and difference in attained BMI at age 10 years scaled to 2 standard deviations of in utero non-freeway NOx with $14.7 \mathrm{ppb}$, first year of life non-freeway NOx with $18.7 \mathrm{ppb}$, and childhood nonfreeway NOx with $9.4 \mathrm{ppb}$

${ }^{*} p<0.05$

with longitudinal BMI measures, movers only, as well as movers with in utero NRAP exposures, and movers with first year of life NRAP exposures suggesting that the NRAP association were not the result of selecting movers for this study (Additional file 10).

Collectively, these results suggest that specific components of NRAP exposure in freeway versus non-freeway mixtures may independently contribute to obesity risk during different periods of early life and childhood. Vehicle exhaust is the main contributor to NRAP and chemical composition of freeway and non-freeway roads have shown to be different due to differences in vehicle types and vehicle volume [29]. For example, heavy duty diesel trucks with compression ignition engines travel most densely on freeways compared to non-freeway roads particularly in Southern California, and diesel truck emissions also differ from spark ignition engine emissions which are primarily gasoline derived passenger vehicles. Furthermore, a study in Texas also showed that three different road types had notable differences in chemical composition due to the varying vehicle types and emissions [30,31]. Due to differences in total volume and emissions from diesel engine versus gasoline engine vehicles, chemical composition downwind of freeway and non-freeway roadways is expected to differ.

Our findings build on previous work in animal studies that have reported associations of early life air pollution exposures and obesity [32, 33]. In mice, in utero exposure to diesel exhaust predisposed offspring to higher weight gain when fed a high fat diet compared to those offspring exposed to filtered air and given a high fat diet [32]. Additionally, Sprague Dawley rats exposed to unfiltered Beijing air pollution prenatally and continuously after birth had significantly higher fat mass at 8 weeks [33]. Together, results from our study coupled with animal models suggest that early life exposures may represent a critical window of exposure where increased
NRAP may result in increased risk for higher childhood BMI trajectories, which in turn may lead to childhood obesity.

The biological mechanisms linking air pollution exposure with increased childhood BMI remain uncertain. However, animal models suggest inflammatory pathways where increased air pollution exposures have been shown to result in higher levels of circulating proinflammatory cytokines, inflammation in the lungs, lower levels of anti-inflammatory cytokines as well as adipose tissue inflammation [33-35]. Exposures may also have effects on the brain via neuroinflammation where increased in utero air pollution exposure was shown to stimulate appetite or anxiety induced over-eating in mice [32]. Additionally, animal models suggest that increased polycyclic aromatic hydrocarbon exposure, a byproduct of traffic combustion, may increase white adipose tissue accumulation and inhibit lipolysis [36, 37]. These animal studies have uncovered some of the potential mechanisms underlying the associations between increased in utero and early life NRAP exposures with obesity. Our study builds on this work by showing longitudinal associations between early life NRAP exposure and BMI growth in children 6-10 years of age.

Despite the strengths of this study, dietary data was unavailable and residual confounding may have occurred since poor diet, such as increased sugar-sweetened beverage consumption, is associated with increased risk of childhood obesity $[38,39]$ and NRAP exposure through lower socioeconomic position [40]. However, the models adjusted for important covariates that may be related to these factors and it is unlikely that results are fully explained by residual confounding. The current study used residential based estimates of NRAP exposure with near-road $\mathrm{NO}_{x}$ concentrations as a marker of NRAP exposures. While exposure misclassification may have occurred, misclassification should be random amongst subjects therefore biasing estimates toward the null. This study was also limited to BMI from annual height and weight measures since direct measures of adiposity were not performed [41]. Lastly, since in utero and first year of life NRAP exposures were highly correlated, we are unable to conclude the relative contribution of each exposure window (i.e., in utero versus first year of life) to increased childhood BMI.

\section{Conclusions}

Our results show that increased first year of life near-road freeway $\mathrm{NO}_{\mathrm{x}}$ exposures are associated with increased velocity of childhood BMI growth trajectory and higher attained BMI at 10 years and remained robust after controlling for multiple confounders as well as childhood near-road freeway $\mathrm{NO}_{\mathrm{x}}$ exposures. Furthermore, increased childhood near-roadway exposures from 
non-freeway sources were associated with increased BMI growth and higher BMI at 10 years, consistent with our past findings. These results, along with other epidemiological and animal studies, implicate environmental exposures such as NRAP as potential risk factors for higher childhood BMI growth and higher attained BMI at age 10 years. These findings have significant public health relevance for intervention since the number of children living near freeways and busy roadways is large and continues to increase [42]. Additional epidemiological and experimental studies are warranted to examine the mechanisms by which early life NRAP exposures may impact early growth trajectories in children.

\section{Additional files}

Additional file 1: Pearson correlation coefficients between in utero/first year of life and childhood NRAP exposure in non-movers and movers in children in the Children's Health Study. (DOCX 14 kb)

Additional file 2: Baseline characteristics of movers and non-movers with early life NRAP exposures and who were enrolled in the longitudinal Children's Health Study. (DOCX $18 \mathrm{~kb}$ )

Additional file 3: Effects of in utero/first year of life and childhood nearroad total $\mathrm{NO}_{x}{ }^{\mathrm{a}}$ exposure on 4-year childhood BMI trajectories. (DOCX 14 $\mathrm{kb})$

Additional file 4: Effects of in utero/first year of life near-road freeway $\mathrm{NO}_{x}$ on 4-year childhood BMI trajectories for male and female children. (DOCX $15 \mathrm{~kb}$ )

Additional file 5: Effects of in utero/first year of life near-road freeway $\mathrm{NO}_{\mathrm{x}}$ on 4-year childhood BMI trajectories for Non-Hispanic White/Hispanic children. (DOCX $15 \mathrm{~kb}$ )

Additional file 6: Effects of in utero/first year of life near-road freeway $\mathrm{NO}_{\mathrm{x}}$ on 4-year childhood BMl trajectories for baseline overweight/obese and normal BMl children. (DOCX $15 \mathrm{~kb}$ )

Additional file 7: Effects of in utero/first year of life near-road freeway $\mathrm{NO}_{x}$ on 4-year childhood BMI trajectories adjusting for birth weight and gestational age. (DOCX $14 \mathrm{~kb}$ )

Additional file 8: Effects of in utero/first year of life and childhood ambient PM $_{2.5}$ exposure on 4-year childhood BMI trajectories. (DOCX 14 $\mathrm{kb})$

Additional file 9: Independent effects of in utero or first year of life near-road freeway $\mathrm{NO}_{x}$ exposure on 4-year childhood BMI trajectories in movers and non-movers. (DOCX $15 \mathrm{~kb}$ )

Additional file 10: Effects of childhood, near-road non-freeway $\mathrm{NO}_{x}$ exposure on 4-year childhood BMI trajectories for children enrolled in the Children's Health Study. (DOCX 14 kb)

\section{Abbreviations}

BMI: Body mass index; CALINE4: California line-source dispersion model; CDC: Centers for Disease Control and Prevention; CHS: Children's Health Study; Cl: Confidence interval; IQR: Interquartile range; LBW: Low birth weight; $\mathrm{NO}_{x}$ : Nitrogen oxides; NRAP: Near-roadway air pollution; $\mathrm{PM}_{2.5}$ : Fine particulate matter $\leq 2.5 \mu \mathrm{m}$ in diameter; ppb: Parts per billion; SD: Standard deviation; SHS: Secondhand smoke

\section{Acknowledgements}

We are indebted to the school principals, teachers, students and parents in each of the study communities for their cooperation. Thank you to all CHS investigators and staff who have made this data possible.

\section{Funding}

This work was funded by the following agencies: Southern California Environmental Health Sciences Center from NIH NIEHS (grants 5P30ES07048 and P30ES007048), T32 Environmental Genomics Training grant from NIH NIEHS (grant T32ES013678), Southern California Children's Environmental Health Center from NIH NIEHS and EPA (grant \#S P01ES022845 and RD83544101-0), NIH NIEHS (grant K99ES027853), and the Hastings Foundation.

Availability of data and materials

Please contact the corresponding author for data requests.

\section{Authors' contributions}

JSK conceived the research question, reviewed the data, performed the data analysis, and wrote the manuscript. TLA and ZC assisted with data analysis, reviewed the results, and contributed to writing of the manuscript. FL provided air pollution exposure data and contributed to manuscript writing. ER managed all study related data and contributed to writing of the manuscript. RH created and maintained air pollution data for life time exposures and contributed to writing of the manuscript. KB provided guidance for the data analysis, reviewed the results, and contributed to writing of the manuscript. FDG conceived the primary study design, obtained funding for the study, reviewed the results, and contributed to writing of the manuscript. All authors have reviewed and approved the final manuscript.

\section{Ethics approval and consent to participate}

Informed consents were obtained from parents and assents from children upon recruitment. This study was reviewed and approved by the Institutional Review Board at the University of Southern California.

\section{Consent for publication}

Not applicable.

\section{Competing interests}

The authors declare that they have no competing interests.

\section{Publisher's Note}

Springer Nature remains neutral with regard to jurisdictional claims in published maps and institutional affiliations.

\section{Author details}

'Department of Preventive Medicine, Division of Environmental Health, Keck School of Medicine, Southern California Environmental Health Sciences Center, University of Southern California, 2001 N. Soto Street, Los Angeles, CA 90032, USA. ${ }^{2}$ Sonoma Technology Inc., Petaluma, CA, USA. ${ }^{3}$ Department of Integrative Physiology, University of Colorado at Boulder, Boulder, CO, USA.

Received: 27 March 2018 Accepted: 26 July 2018

Published online: 14 September 2018

\section{References}

1. Ogden $\mathrm{CL}$, Carroll MD, Kit BK, Flegal KM. Prevalence of childhood and adult obesity in the United States, 2011-2012. JAMA. 2014:311(8):806-14.

2. Singh AS, Mulder C, Twisk JW, van Mechelen W, Chinapaw MJ. Tracking of childhood overweight into adulthood: a systematic review of the literature. Obes Rev. 2008;9(5):474-88.

3. Ward ZJ, Long MW, Resch SC, Giles CM, Cradock AL, Gortmaker SL. Simulation of growth trajectories of childhood obesity into adulthood. N Engl J Med. 2017;377(22):2145-53.

4. Weiss R, Kaufman FR. Metabolic complications of childhood obesity: identifying and mitigating the risk. Diabetes Care. 2008;31(Suppl 2):S310-6.

5. Franks PW, Hanson RL, Knowler WC, Sievers ML, Bennett PH, Looker HC. Childhood obesity, other cardiovascular risk factors, and premature death. N Engl J Med. 2010;362(6):485-93.

6. Freedman DS, Mei Z, Srinivasan SR, Berenson GS, Dietz WH. Cardiovascular risk factors and excess adiposity among overweight children and adolescents: the Bogalusa Heart Study. J Pediatr. 2007;150(1):12-7. e2

7. Hannon TS, Rao G, Arslanian SA. Childhood obesity and type 2 diabetes mellitus. Pediatrics. 2005;116(2):473-80. 
8. Ogden CL, Carroll MD, Fryar CD, Flegal KM. Prevalence of Obesity Among Adults and Youth: United States, 2011-2014. NCHS Data Brief 2015(219):1-8. https://www.cdc.gov/nchs/data/databriefs/db219.pdf.

9. Jerrett M, McConnell R, Wolch J, Chang R, Lam C, Dunton G, Gilliland F, Lurmann F, Islam T, Berhane K. Traffic-related air pollution and obesity formation in children: a longitudinal, multilevel analysis. Environ Health. 2014;13:49.

10. McConnell R, Shen E, Gilliland FD, Jerrett M, Wolch J, Chang CC, Lurmann F, Berhane K. A longitudinal cohort study of body mass index and childhood exposure to secondhand tobacco smoke and air pollution: the Southern California Children's health study. Environ Health Perspect. 2015;123(4):360-6.

11. Jerrett M, McConnell R, Chang CC, Wolch J, Reynolds K, Lurmann F, Gilliland F, Berhane K. Automobile traffic around the home and attained body mass index: a longitudinal cohort study of children aged $10-18$ years. Prev Med. 2010;50(Suppl 1):S50-8.

12. Janesick AS, Blumberg B. Obesogens: an emerging threat to public health. Am J Obstet Gynecol. 2016;214(5):559-65.

13. Rundle A, Hoepner L, Hassoun A, Oberfield S, Freyer G, Holmes D, Reyes M, Quinn J, Camann D, Perera F, Whyatt R. Association of childhood obesity with maternal exposure to ambient air polycyclic aromatic hydrocarbons during pregnancy. Am J Epidemiol. 2012;175(11):1163-72.

14. Mao G, Nachman RM, Sun Q, Zhang X, Koehler K, Chen Z, Hong X, Wang G, Caruso D, Zong G, et al. Individual and Joint Effects of Early-Life Ambient PM2.5 Exposure and Maternal Pre-Pregnancy Obesity on Childhood Overweight or Obesity. Environ Health Perspect. 2017;125(6):067005

15. Fioravanti S, Cesaroni G, Badaloni C, Michelozzi P, Forastiere F, Porta D. Traffic-related air pollution and childhood obesity in an Italian birth cohort. Environ Res. 2018;160:479-86.

16. Adair LS. Child and adolescent obesity: epidemiology and developmental perspectives. Physiol Behav. 2008;94(1):8-16.

17. Dietz WH. Critical periods in childhood for the development of obesity. Am J Clin Nutr. 1994;59(5):955-9.

18. Dadvand P, Parker J, Bell ML, Bonzini M, Brauer M, Darrow LA, Gehring U, Glinianaia SV, Gouveia N, Ha EH, et al. Maternal exposure to particulate air pollution and term birth weight: a multi-country evaluation of effect and heterogeneity. Environ Health Perspect. 2013;121(3):267-373.

19. Ghosh JK, Wilhelm M, Su J, Goldberg D, Cockburn M, Jerrett M, Ritz B. Assessing the influence of traffic-related air pollution on risk of term low birth weight on the basis of land-use-based regression models and measures of air toxics. Am J Epidemiol. 2012;175(12):1262-74.

20. Pedersen M, Giorgis-Allemand L, Bernard C, Aguilera I, Andersen AM, Ballester F, Beelen RM, Chatzi L, Cirach M, Danileviciute A, et al. Ambient air pollution and low birthweight: a European cohort study (ESCAPE). Lancet Respir Med. 2013;1(9):695-704.

21. Ong KK, Ahmed ML, Emmett PM, Preece MA, Dunger DB. Association between postnatal catch-up growth and obesity in childhood: prospective cohort study. BMJ. 2000;320(7240):967-71.

22. Fleisch AF, Rifas-Shiman SL, Koutrakis P, Schwartz JD, Kloog I, Melly S, Coull BA, Zanobetti A, Gillman MW, Gold DR, Oken E. Prenatal exposure to traffic pollution: associations with reduced fetal growth and rapid infant weight gain. Epidemiology. 2015;26(1):43-50.

23. McConnell R, Berhane K, Yao L, Jerrett M, Lurmann F, Gilliland F, Kunzli N, Gauderman J, Avol E, Thomas D, Peters J. Traffic, susceptibility, and childhood asthma. Environ Health Perspect. 2006;114(5):766-72.

24. Kuczmarski RJ, Ogden CL, Guo SS, Grummer-Strawn LM, Flegal KM, Mei Z, Wei R, Curtin LR, Roche AF, Johnson CL. 2000 CDC growth charts for the United States: methods and development. Vital Health Stat 11 2002(246):1-190.

25. Texas A\&M University Geoservices. Available online at http://geoservices. tamu.edu.

26. Benson P. A review of the development and application of the CALINE3 and 4 models. Atmos. Environ. Part B. 1992;26(3):379-90.

27. Diggle P, Heagerty P, Liang K-Y, Zeger S. Analysis of longitudinal data. 2002. Oxford Statistical Science Series 2002.

28. Berhane K, Gauderman W, Stram D, Thomas D. Statistical issues in studies of the long term effects of air pollution: the Southern California Children's health study. Stat Sci. 2004;19(3):414-49.

29. Fujita EM, Zielinska B, Campbell DE, Arnott WP, Sagebiel JC, Mazzoleni L, Chow JC, Gabele PA, Crews W, Snow R, et al. Variations in speciated emissions from spark-ignition and compression-ignition motor vehicles in
California's south coast air basin. J Air Waste Manag Assoc. 2007:57(6): 705-20.

30. Clements AL, Jia YL, Denbleyker A, McDonald-Buller E, Fraser MP, Allen DT, Collins DR, Michel E, Pudota J, Sullivan D, Zhu YF. Air pollutant concentrations near three Texas roadways, part II: chemical characterization and transformation of pollutants. Atmos Environ. 2009:43(30):4523-34.

31. Zhu YF, Pudota J, Collins D, Allen D, Clements A, DenBleyker A, Fraser M, Jia YL, McDonald-Buller E, Michel E. Air pollutant concentrations near three Texas roadways, Part I: Ultrafine particles. Atmos Environ. 2009;43(30): 4513-22.

32. Bolton JL, Smith SH, Huff NC, Gilmour MI, Foster WM, Auten RL, Bilbo SD. Prenatal air pollution exposure induces neuroinflammation and predisposes offspring to weight gain in adulthood in a sex-specific manner. FASEB J. 2012;26(11):4743-54.

33. Wei Y, Zhang JJ, Li Z, Gow A, Chung KF, Hu M, Sun Z, Zeng L, Zhu T, Jia G, et al. Chronic exposure to air pollution particles increases the risk of obesity and metabolic syndrome: findings from a natural experiment in Beijing. FASEB J. 2016;

34. Sun Q, Yue P, Deiuliis JA, Lumeng CN, Kampfrath T, Mikolaj MB, Cai Y, Ostrowski MC, Lu B, Parthasarathy $\mathrm{S}$, et al. Ambient air pollution exaggerates adipose inflammation and insulin resistance in a mouse model of dietinduced obesity. Circulation. 2009;119(4):538-46.

35. Liu C, Xu X, Bai Y, Wang TY, Rao X, Wang A, Sun L, Ying Z, Gushchina L, Maiseyeu A, et al. Air pollution-mediated susceptibility to inflammation and insulin resistance: influence of CCR2 pathways in mice. Environ Health Perspect. 2014;122(1):17-26.

36. Irigaray $P$, Ogier $V$, Jacquenet $S$, Notet $V$, Sibille $P$, Mejean L, Bihain BE, Yen FT. Benzo[a]pyrene impairs beta-adrenergic stimulation of adipose tissue lipolysis and causes weight gain in mice. A novel molecular mechanism of toxicity for a common food pollutant. FEBS J. 2006;273(7):1362-72.

37. Ravindra K, Sokhi R, Van Griekenb R. Atmospheric polycyclic aromatic hydrocarbons: source attribution, emission factors and regulation. Atmos Environ. 2008;42(13):2895-921.

38. Ludwig DS, Peterson KE, Gortmaker SL. Relation between consumption of sugar-sweetened drinks and childhood obesity: a prospective, observational analysis. Lancet. 2001;357(9255):505-8.

39. Davis JN, Whaley SE, Goran MI. Effects of breastfeeding and low sugarsweetened beverage intake on obesity prevalence in Hispanic toddlers. Am J Clin Nutr. 2012;95(1):3-8.

40. Green RS, Smorodinsky S, Kim JJ, McLaughlin R, Ostro B. Proximity of California public schools to busy roads. Environ Health Perspect. 2004;112(1): 61-6

41. Freedman DS, Wang J, Maynard LM, Thornton JC, Mei Z, Pierson RN, Dietz WH, Horlick M. Relation of BMI to fat and fat-free mass among children and adolescents. Int J Obes. 2005;29(1):1-8.

42. Greenbaum D. HEl Panel on the Health Effects of Traffic-Related Air Pollution. Traffic- related air pollution: a critical review of the literature on emissions, exposure, and health effects. HEl Special Report 17. Boston: Health Effects Institute; 2010.
Ready to submit your research? Choose BMC and benefit from:
- fast, convenient online submission
- thorough peer review by experienced researchers in your field
- rapid publication on acceptance
- support for research data, including large and complex data types
- gold Open Access which fosters wider collaboration and increased citations
- maximum visibility for your research: over $100 \mathrm{M}$ website views per year
At BMC, research is always in progress.
Learn more biomedcentral.com/submissions 